\title{
Microfinance Institutions (MFIs) Intervention in Poverty Alleviation of Households in Lopez, Quezon Province, Philippines
}

\author{
Veronica ALMASE \\ Business Administration Department, Polytechnic University of the Philippines -Lopez, Quezon Philippines \\ Email: vsalmase@pup.edu.ph / aeronalmase@yahoo.com
}

\begin{abstract}
This paper investigates Microfinance Institutions (MFIs) Intervention in poverty alleviation of households in the locality of Lopez, Quezon province, Philippines. It focuses on five specific objectives to: Determine the personal profile of MFIs household members, their membership profile, examine the goal congruence between MFIs and households, investigate the circumstances during MFIs intervention and, finally find out threats in availing loans from MFIs. This paper adopts quantitative type of research primarily the descriptive questions survey where 117 were considered as the representative sample of MFIs in the municipality. Likewise, purposive sampling was used in the determination of samples and survey form for data collection. This study utilized the SPSS to generate the frequency distribution and weighted mean. It was revealed in the analysis that microfinance interventions that offer both savings and loans contributed to a higher standard of living of households. More so, the results show that microfinance institutions provide supplemental income for families which may adhere to basic family needs, health, education, and lessen debts to specific persons. Therefore, It was found out that both microfinance savings and microfinance credit appreciably and undoubtedly changed the conditions of every household after availing the MFIs services. The study recommends that MFIs should continuously pay closer attention on their interventions that will provide assistance that are favorable to the welfare of every member and the society as well.
\end{abstract}

Keywords

Alleviation, households, interventions, members, microfinance institution

Article Received: XX Xxx 2021, Revised: XX Xxx 2021, Accepted: XX Xxx 2021

\section{Introduction}

Microfinance institution is increasingly growing bringing the concept of helping the poor through microcredit, insurance, small savings and other financial services. Their primary target market are female which could be found in most developing countries. In addition to poverty alleviation as the main goal of the institution, the latter aims to provide ingress to credit and women empowerment[1]. Subsequently, women contributed immensely as household partner in the families and to the development of economy as well that lead to social change[2]. One of the studies mentioned that, MFIs were substantially addressing the needs of the poor who are less deprived in accessing the services of commercial banks [3]. Over the years, the growth of microfinance institutions in the town of Lopez was quietly established suchlike; Center for Agriculture and Development (CARD), Agricultural and Rural Development for Catanduanes Inc. (ARDCI), ASA Philippines, Rural Bank of Atimonan (RBA), Tulay sa Pagunlad Incorporated (TSPI) Pagasa, Light
Microfinance and others seems to be popular specifically to the households in Lopez, Quezon. It appeal to the interest of the researcher to conduct a study on how these microfinance institutions affect the lives of selected households in Lopez in terms of the services they offer. Likewise, the reasons of households for availing loan assistance service from MFI's, the problems they encountered from MFI's, their preference factors to MFI's over other financial intermediaries like banks, significant changes in the condition of households after availing the services of MFIs and some problems these households encounter from the service provider. Additionally, microfinance or financial services extended to low-income individuals or those with no access to formal banking, is thriving in the country. The services offered were usually in the form of small loans that are especially important given that $99.6 \%$ of the economy is made up of micro, small, and medium enterprises (MSMEs) [4]. According to Governor Amando TetangcoJr. in the gist of his message at the launch of the $14^{\text {th }}$ Citi Micro entrepreneurship Awards on May 17, 2016, microfinance loans increased $333 \%$ to $\mathrm{P}$ 
11.3 billion in 2015 from 2.6 billion in 2002 . Also, he accessorial that the quantity of borrowers jumped $277 \%$ to 1.47 million from 390,635 because the number of banks providing microfinance loans raised $43 \%$ to 170 from 119 . It indicates that microfinance industry plays a vital role in helping the community to have a supplemental income for their families.

Microcredit as the major service of MFIs contributed significantly on business undertakings of the member-borrower and also to some household expenses [5]. However, one literature argued that microfinance was ineffective in poverty struggle and not a cure-all for development. Hence, some MFIs who are profitoriented had encountered problems among members [6]. Evident of these are the shortfall of financial steadiness, uninhibited development, cultural and value restrain, planned sharp practice, state barrier and interventions [7].

Nowadays, increasing number of microfinance institutions plays a significant role especially in developing nations/regions . For this reason, commercial banks allocate funding for the MFIs [8]. Some studies proved that the latter is a crucial tool to infuse the gap of typical banks' restriction in serving the financially disadvantaged individuals. Expressly, through MFIs, financial services becomes easy and accessible that will concede them to get off poverty[9]. For this matter, MFI members were able to continuously patronize the services provided because it requires only minimum requirements.

Households in the locale of the study find it necessary to have an access to microfinance institutions because most of them would like to have a supplemental means of support to their family needs and expenditures.

\section{Statement of the Problem}

This paper would like to determine how Microfinance institution (MFI) intervenes to alleviate poverty of households in Lopez, Quezon. Explicitly, it intends to achieve the following:

1. To determine the intervention of microfinance institutions on poverty alleviation of households

2. To determine goal congruence of both households and MFIs

3. To examine the preference factors of households in choosing MFIs among other financial institutions
4. To establish issues on the intervention of MFIs

5. To find out threats in availing the services of MFIs

\section{Literature Review}

Through a study conducted on the impact of MFI on living standards, empowerment and poverty alleviation in Ethiopia, It was revealed that there were positive impact provided by the MFIs as to improved standard of living, sending children to school, provision of medical support and basic needs of their families and economically empowered people [9]. Likewise, microcredit is still the domineering feature of microfinance that will create remarkable impact [10]. It was also proven that microfinance intervention alleviate poverty at the household level. MFIs' householdcustomer in the rural areas are highly sensitive to the big amount of credit compared to those living in the urban areas [11].

One article argued that microfinance can play an important role in financial development, thus, it is a call to have focus on strengthening development policy tied-up with monetary burgeoning, economic upswing, and indigence reduction [12]. There are MFIs who are experiencing somewhat lesser extent of economic liberty and that economic state intervention can lessen the sustenance of their operation [13]. In order to improve the impact of microfinance institutions, some researchers indicate notably that retooling and re-engineering of the microfinance scheme will help set the right path for the government to ensure macroeconomic environment coupling with the micro businesses to excel in the country [14].

In terms of preferential factors of choosing MFIs, one study revealed that loan officers had a great impact for customers who would like to avail loans from them. Also, this proved that quality of service is most important than simply accessing the funds from the institution [15]. On the other hand, there is no proof that insurance as part of MFIs product does not affect the savings feature in the microfinance market [16]. The market of microfinance shall always consider several factors that will ultimately provide customer satisfaction. Considering the fact that microfinance helps alleviate poverty and they continue to provide assistance to the poor, problems still occur when it comes to repayment. These problems include 
customer's attitude, other financial obligations and inexperience in business undertaking [17]. In the locale of this study, there is a continuous increase on the number of microenterprise members who would like to avail the services of MFIs for the benefits of their families. It is not surprisingly that most of them survived to have a better life which in turn gave credits to this program.

\section{Materials and Methods}

This paper adopts quantitative type of research primarily the descriptive questions survey where 117 were considered as the representative sample of MFIs in the municipality. Likewise, purposive sampling was used in the determination of samples and survey form for data collection. Selected three Barangay has a total household of 1708 in which the researcher used Sloven's formula to arrive at a sample size of 117 . The number of households in the three barangays in Lopez was provided by the Municipal Planning and Development Coordinator (MPDC) in Lopez,Quezon. The survey questionnaire intended to this study was validated by five experts in the locality. Furthermore, reliability test was administered through pretesting among 20 households through the use of Cronbach alpha. Part one of the questionnaire comprises series of questions to find out the profile of the respondents. Other information requested from selected household is average family monthly income, source of income and number of family members. Part two of the questionnaire is the membership profile of household to MFI's where part three is a series of statements used as indicators in finding the goal congruence of households and MFIs. The researcher used the Likert survey so that respondents will respond easily.

More so, utilizing survey instrument in the study helped the researcher to accomplish the quantitative research design through the use of statistics needed for data interpretations. Likert scale, shown below, was used to shed light in rating the indicators in the instrument.

$\begin{array}{lll}3.25-4.00 & 4 & \text { Strongly Agree } \\ 2.50-3.24 & 3 & \text { Agree } \\ 1.75-2.49 & 2 & \text { Disagree } \\ 1.00-1.74 & 1 & \text { Strongly Disagree }\end{array}$

In order to generate the frequency distribution and weighted mean, SPSS was used.

\section{Results and Discussion}

Analysis and interpretation of data gathered through the administered questionnaires were presented in this section.

It was revealed in the study that majority of the respondents were in the age range of 48 and above and mostly are female respondent. As to civil status of the respondents, most of them were married who earned a monthly income of Php $1,000.00$ to Php 10,000.00 with a congruent number of responses in terms of the source of income, whom they earned from business and employer. Majority of them has 3-4 and 6-8 household members.

When it comes to members' profile, majority of them is engaged in only one microfinance institution which is the Center for Agriculture and Development (CARD) with the highest number of household members whom most of the latter availed Php 2,000.00 to Php 10,000.00 amount of loan. Loan approval was based primarily on personal background check (personal loan) and guarantor-based loan. Households indicate that Savings Small loans are the most preferred services they availed from MFIs.

When it comes to the respondents evaluation on the congruence of goals to households, MFIs disclosed the following findings:

$\checkmark$ Respondents agreed that support for daily needs, lack of budget, children's education, and pay other debts are the reasons for availing loans from MFIs. (Table 1)

$\checkmark$ They also agreed that rising personal and family spending needs, basic commodity prices, and insufficient income of the family are the problems that caused them to look for MFIs intervention. (Table 2)

$\checkmark \quad$ In terms of preference factors on how do they chose microfinance institutions, they agreed that it's because of the following: Interest rates are more favorable and justifiable; with minimum requirements; credit selection is more liberal; short processing time; and lesser installment amount. (Table 3)

As to circumstances during MFIs intervention, the study revealed the following:

$\checkmark$ As to terms and conditions provided by MFIs, respondents agreed that savings were established in the institution, inclusions of 
insurance in the program, proceeds received is net of interest and service charge, and there is a steady increase of credit line.(Table 4)

All respondents agreed that there were significant changes in their conditions after availing the services from MFIs. Specifically, it provides supplemental income for the family, it creates capacity to adhere to family needs, and it provides supplemental income for health and education and, helps them to lessen debts from other persons. (Table 5)

There are no threats or problems revealed by the respondents in availing the services of MFIs in the locality.

Lastly, the effects of microfinance intervention on poverty alleviation of households were depicted in Fig.1. (Appendix 1)

\section{Conclusions}

Microfinance concepts are very much helpful and appropriate for the low-income households in the society and it alleviates poverty of the latter through the services offered by MFIs. The increasing number of MFIs member is a good indication that this industry provides better offerings or services for microfinance clients. It was found out that households avail the services of MFIs because it supplements the income of the family; however, the lowest level of agreement was due to health issues or purposes. Households earning 1,000 to 5,000 are mostly the microfinance clients. According to SWS survey, "median food poverty threshold for Metro Manila was P9,000 (\$192) and P5,000 (\$107) for Luzon, Visayas and Mindanao" [18].

The findings of this study opposed from those of "Reference [19], rumored that a number of the poor individuals in a specific area are willing solely to save lots of, and not to borrow. It can also be concluded that the source of income of these households who are MFIs clients are microbusiness owners. More so, it was concluded that the respondents were not joining more than one MFI at the same time. Likewise, these households are experiencing the increasing amount of personal and family spending need, thus they join and enjoy the benefits given by MFIs. In short, findings of this study coincide with Dilruba, et al.,2018 where microcredit contributed to poverty alleviation of people and eventually improve the standard of living through the raised income level [20].

Therefore, It was concluded that a little modification to microfinance concepts shall be given attention specifically to savings, loans and insurance.

Based on the conclusions, the researcher would like to recommend the following:

1. Regulate the determination of loanable amount for clients since most of them are earners of their own business.

2. The amount of loan granted to clients should be comparable to the amount of savings

3. and should formulate policy that will regulate the loan of members since they revealed that it is lesser than other financial institutions.

4. MFIs should come up with a new product/s that will encourage members to use their money wisely and productively as they borrow it from MFIs.

5. Comparative Study on the Practices of different MFIs in the area should be conducted.

6. Strategies implemented by different MFIs must be carefully analysed so that each of them will offer standardized program/services to clients.

\section{Acknowledgments}

My sincere appreciation to the following persons who administered the distribution of survey questionnaires and retrieved the instruments afterwards:
Aizel O. Almase
Jobelle M. Arevalo
Renelee D. Baldoz
Patricia Carmel M. Pabillar
Ana Rose M. Sarcino

\section{References}

[1] Haile, H. B., Bock, B., \& Folmer, H. (2012). Microfinance and female empowerment: Do institutions matter? Women's Studies International Forum, 35(4), 256-265. https://doi.org/10.1016/j.wsif.2012.04.001

[2] Cresenta Shakila Motha, L., Amudha, R., Alamelu, R., Nalini, R., \& Indhu Bobendra, R. (2017). Women empowerment through self help groups - Microfinance as a tool. International Journal of Applied Business and Economic Research, 15(7), 397-405. 
[3] Hermes, N., Lensink, R., \& Meesters, A. (2011). Outreach and Efficiency of Microfinance Institutions. World Development, 39(6), 938-948. https://doi.org/10.1016/j.worlddev.2009.10. $\underline{018}$

[4] BSP (2015). Facts regarding Microfinance. Retrieved March 7, 2019, from http://www.bsp.gov.ph/about/advocacies_mi cro_facts.asp\#1.

[5] Imai, K. S., Gaiha, R., Thapa, G., \& Annim, S. K. (2012). Microfinance and Poverty-A Macro Perspective. World

Development, 40(8), 1675-1689. https://doi.org/10.1016/j.worlddev.2012.04. $\underline{013}$

[6] Ghosh, J. (2013). Microfinance and the challenge of financial inclusion for development. Cambridge Journal of Economics, 37(6), 1203-1219. https://doi.org/10.1093/cje/bet042

[7] Saeed, M. S. (2014). Microfinance Activities and Factors Affecting the Growth of Microfinance in Developed \& Developing Countries. International Finance and Banking, 1(1), 39. https://doi.org/10.5296/ifb.v1i1.5473

[8] Miled, K. B. H., \& Rejeb, J.-E. B. (2015). Microfinance and Poverty Reduction: A Review and Synthesis of Empirical Evidence. Procedia - Social and Behavioral Sciences, 195, 705-712. https://doi.org/10.1016/j.sbspro.2015.06.339

[9] Chirkos, A. Y. (2014). Impact of microfinance on living standards, empowerment and poverty alleviation of poor people in Ethiopia. Journal of Finance and Accounting, 5, 43-67.

[10] Yeboah, E. (2017). The Impact of Microfinance on Grassroot Development: Evidence from Smes in Kwabre East District of Ashanti Region of Ghana. Open Journal of Business and Management, 05(04), 577-591. https://doi.org/10.4236/ojbm.2017.54050

[11] Annim, S. K. (2018). Outreach and the poverty-reducing effect of microfinance in Ghana. Enterprise Development and Microfinance, 29(2), 145-171. https://doi.org/10.3362/1755-1986.17-00020

[12] Barr, M. S. (2005). Microfinance and Financial Development. Michigan Journal of
International Law, 26(2000), 271-296.I

[13] Crabb, P. (2008). Economic freedom and the success of microfinance institutions. Journal of Developmental Entrepreneurship, 13(2), 205-219.

https://doi.org/10.1142/S108494670800093 $\underline{4}$

[14] Agbaeze, E. K., \& Onwuka, I. (2014). Microfinance Banks and Rural Development: The Nigeria Experience. International Journal of Rural Management, 10(2), 147-171. https://doi.org/10.1177/0973005214546597

[15] Joo, H. (2012). Commercial microfinance in Korea: Outreach, customer choice and satisfaction, and impact. ProQuest Dissertations and Theses. University of Southern California. Retrieved from http://cyber.usask.ca/login?url=https://www. proquest.com/docview/1026590869?account $\mathrm{id}=14739 \mathrm{http}: / /$ sfx.usask.ca/usask?url_ver= Z39.88-

2004\&rft_val_fmt=info:ofi/fmt:kev:mtx:diss ertation \& genre $=$ dissertations $+\% 26+$ theses $\&$ sid=ProQ:ProQuest+Dissertations+\%26+Th $\underline{\mathrm{es}}$

[16] Kwon, W. J. (2010). An analysis of organisational, market and socio-cultural factors affecting the supply of insurance and other financial services by microfinance institutions in developing economies. Geneva Papers on Risk and Insurance: Issues and Practice, 35(1), 130 160. https://doi.org/10.1057/gpp.2009.32

[17] Nawai, N., \& Shariff, M. N. M. (2013). Loan Repayment Problems in Microfinance Programs that use Individual Lending Approach: A Qualitative Analysis. Journal of Transformative Entrepreneurship, 92-99. https://doi.org/10.14239/jte.2013.01203

[18] Social Weather Stations, Available at: https://www.sws.org.ph/swsmain/artcldispp age/?artcsyscode=ART-20170428131124, accessed November, 2020.

[19] Rhyne, E. \& Otero M. (1992). Financial Services of Microfinances: Principles and Institutions. World Development 20/11.

[20] Khanam, D., Mohiuddin, M., Hoque, A. et al. Financing micro-entrepreneurs for poverty alleviation: a performance analysis of microfinance services offered by BRAC, ASA, and Proshika from Bangladesh. J Glob 


\section{Entrepr Res 8, $27 \quad$ (2018).}

https://doi.org/10.1186/s40497-018-0114-6

\section{APPENDICES}

\section{Appendix 1:}

Fig. 1.Effects of Microfinance Intervention on Poverty Alleviation of Households

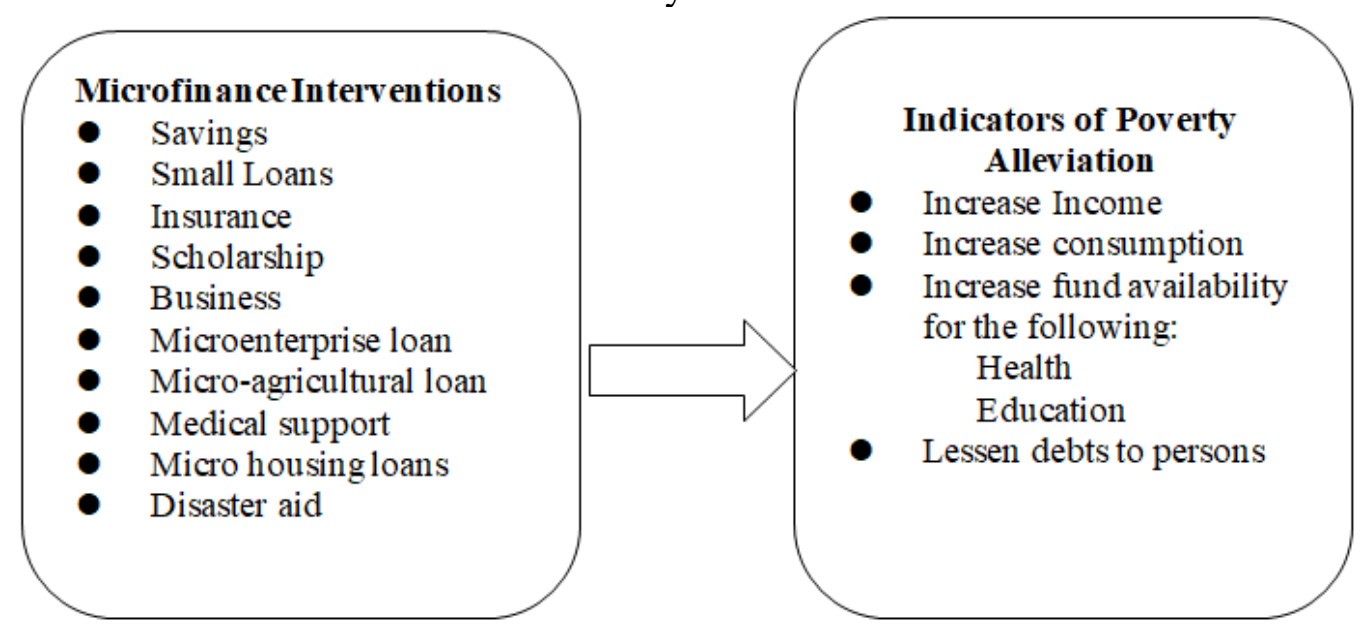

Appendix 2: Table Presentation of Research Results

Table 1: Weighted Mean and Descriptive Interpretation of the Respondents According to Reasons for Availing Loan Assistance Service from MFI's

\begin{tabular}{lcc}
\hline \hline & Weighted Mean & Descriptive Interpretation \\
\hline To support for daily income & 2.9 & Agree \\
Lack of budget for family needs & 2.75 & Agree \\
To pay other debts & 2.64 & Agree \\
For educational expenses & 2.74 & Agree \\
For health purposes & 2.03 & Disagree \\
\hline \hline
\end{tabular}

Table 2: Weighted Mean and Descriptive Interpretation of the Respondents According to Problems Encountered Needing Loan Assistance Service from MFI's

\begin{tabular}{lcc}
\hline \hline & Weighted Mean & Descriptive Interpretation \\
\hline Rising prices of basic commodities & 2.73 & Agree \\
Rising personal and family spending needs & 2.81 & Agree \\
For health purposes & 2.03 & Disagree \\
\hline \hline
\end{tabular}

Table 3: Weighted Mean and Descriptive Interpretation of the Respondents According to Preference factors to MFI's over other intermediaries

Credit selection is more liberal

Interest rates are more favorable and justifiable

Loan processing is done in a short period of time

Requirements are minimal

Daily collection was made

Amount of installment payment is lesser
Weighted Mean Descriptive Interpretation

$\begin{array}{lc}3.09 & \text { Agree } \\ 3.18 & \text { Agree } \\ 3.08 & \text { Agree } \\ 3.16 & \text { Agree } \\ 2.16 & \text { Disagree } \\ 2.92 & \text { Agree }\end{array}$


Table 4: Weighted Mean and Descriptive Interpretation of the Respondents According to Issues Related to Microfinance Terms and Conditions

Proceeds received is net interest and service charge

Pull-out of properties upon default payment

Co-makers become liable upon default payment

Additional penalties and charges upon default of payment

Slow increase of credit line

Inclusion of insurance policies

Establishment of savings to MFIs

\section{Weighted Mean Descriptive Interpretation}

2.89

2.09

2.40

2.04

2.59

3.04

3.13
Agree

Agree

Agree

Disagree

Agree

Agree

Agree

Table 5: Weighted Mean and Descriptive Interpretation of the Respondents According to Significant Changes in the Conditions of Households After Availing the Service of MFI's

\begin{tabular}{lcc}
\hline \hline & Weighted Mean & Descriptive Interpretation \\
\hline There is a supplemental income of the family & 3.03 & Agree \\
Lesser debts to persons & 2.79 & Agree \\
Capacity to adhere family needs & 2.91 & Agree \\
Education is easier & 2.82 & Agree \\
Supplemental income for health & 2.88 & Agree \\
\hline
\end{tabular}

